\title{
In Vitro Propagation and Nuclear DNA Content of Tripleurospermum Insularum (Asteraceae) - A Critically Endangered Insular Endemic Species From Turkey
}

Huseyin Inceer ( $\boldsymbol{\nabla}$ inceer@ktu.edu.tr)

Karadeniz Technical University: Karadeniz Teknik Universitesi https://orcid.org/0000-0003-1344-8747

Mustafa Cuce

Giresun University: Giresun Universitesi

Kemal Vehbi Imamoglu

Karadeniz Technical University: Karadeniz Teknik Universitesi

Tugba Ergin

Karadeniz Technical University: Karadeniz Teknik Universitesi

Ali Omer Ucler

Karadeniz Technical University: Karadeniz Teknik Universitesi

\section{Research Article}

Keywords: Ex situ conservation, micropropagation, Tripleurospermum insularum, nuclear DNA, critically endangered, insular endemic

Posted Date: February 23rd, 2021

DOI: https://doi.org/10.21203/rs.3.rs-219544/v1

License: (1) (1) This work is licensed under a Creative Commons Attribution 4.0 International License. Read Full License

Version of Record: A version of this preprint was published at Plant Biosystems - An International Journal Dealing with all Aspects of Plant Biology on January 18th, 2022. See the published version at https://doi.org/10.1080/11263504.2022.2029969. 


\section{Abstract}

Tripleurospermum insularum Inceer \& Hayirlioglu-Ayaz (Asteraceae) is a critically endangered endemic species in Turkey that is face the risk of extinction as a result of the fragmentation of its habitat as well as overgrazing and trampling of its natural population. However, the protocol for micropropagation of this threatened species has not been developed yet. Here, its regeneration ability on MS media supplemented with different plant growth regulators were evaluated using nodal segments. The higher number and length of shoot per explant was achieved with the addition $4.6 \mu \mathrm{M}$ ZEA and $0.5 \mu \mathrm{M}$ IAA to the culture medium. Besides, the highest node number of shoot per explant was obtained from MS medium supplemented with $4.6 \mu \mathrm{M}$ ZEA and $0.5 \mu \mathrm{M}$ IBA. Flow cytometric analysis also revealed that most of the in vitro developed shoots of $T$. insularum possessed similar nuclear DNA content as well as ploidy level as initial material and plants from natural population. In vitro rooting of shoots was achieved at $100 \%$ efficiency containing $2.9 \mu \mathrm{M}$ IAA. Rooted and well-developed plantlets were initially acclimatized under greenhouse conditions and then moved to the botanical garden, where they matured and flowered. Finally, $76 \%$ and $74 \%$ survivals were achieved during the acclimatization process, respectively. This is the first report of a successfully developed micropropagation protocol of threatened $T$. insularum for its ex situ conservation.

\section{Introduction}

The overall loss of biodiversity as well as the number of threatened plant species in the world has increased in recent years due to several anthropogenic pressures and/or environmental factors (Corral et al. 2011). Therefore, it is imperative to implement conservation strategies for the conservation and propagation of phytogenetic resources from each geographic region (Assédé et al. 2018; Deplazes-Zemp 2018; Ramírez-Mosqueda et al. 2019).

The current International Union for Conservation of Nature (IUCN) Red List categories and criteria are constructed to assess the threatened status of species or lower taxa on global or sub-global (national or regional) levels as a means of classifying the relative risk of extinction of taxon (Inceer and Aksu Kalmuk 2019). Additionally, IUCN Red List database shows that plant extinctions are dominated by insular species, and the extinction data are associated with lower competitive ability and anthropogenic factors (Gray 2018). Indeed, insular species are exposed to multiple threats, such as invasions, land use change, and global climate change (Caujapé-Castells et al. 2010; Kueffer et al. 2010; Bellard et al. 2013; Harter et al. 2015; Médail 2017). This general trend is particularly alarming in the islands and islets of the Mediterranean Basin, one of the main centers of plant diversity (e.g. Cañadas et al. 2014; Médail 2017; Cogoni et al. 2019).

Ex situ conservation methods have played an important role in the conservation of threatened plants (Coste et al. 2012). In this context, in vitro culture techniques have permitted an increasingly important viable system for rapid, true-to-type mass multiplication as well as conservation of threatened endemic and rare species (Piovan et al. 2010; Grigoriadou et al. 2011; Mallón et al. 2011; Wadl et al. 2011; Valletta et al. 2015). Furthermore, the genetic diversity of local ecotypes can be maximized if plants are multiplied from seeds (Benson et al. 2000a; Coste et al. 2012).

Tripleurospermum Sch.Bip. is a small genus of the tribe Anthemideae of the family Asteraceae with ca. 40 species that is mainly distributed in Europe, temperate Asia, North America and North Africa (Oberprieler et al. 2007). Tripleurospermum insularum Inceer \& Hayirlioglu-Ayaz is an insular endemic species with a highly restricted geographic range in Turkey, and is known from the single population in Gökçeada, one of the Aegean Islands (Inceer and Hayirlioglu-Ayaz 2014). It grows in open places and on rocky slopes in Gökçeada. On the other hand, T. insularum has a pharmaceutical potential (Zeljkovic et al. 2015; Colak et al. 2017), similarly to other endemic taxa of Tripleurospermum (Cansaran et al. 2007; Altundag and Ozturk 2011; Han and Bulut 2015; Mohammadi et al. 2016).

According to Inceer and Hayırlıoglu-Ayaz (2014), T. insularum is classified within CR category of IUCN. The Red List extinction data of this species are associated with lower competitive ability and anthropogenic factors such as overgrazing, trampling and fragmentation. The population is therefore facing extinction in the near future, unless in situ and/or ex situ conservation strategies are adopted as soon as possible. To our knowledge, no investigations have been carried out on the in vitro culture of members of the genus Tripleurospermum. The aim of the present study is to develop the efficient in vitro micropropagation protocol for the threatened T. insularum and to evaluate the genetic fidelity of regenerants in order to ex situ conservation of this insular endemic species.

\section{Material And Methods}




\section{Plant material and achene germination}

The mature achenes of $T$. insularum intended for evaluation as explants were supplied from the seed collection of Dr. Huseyin Inceer deposited at $4^{\circ} \mathrm{C}$ at the Karadeniz Technical University, Department of Biology, Trabzon (Çanakkale, Gökçeada, $30 \mathrm{~m}$ a.s.l. 17 April 2009, Inceer 717).

Initially, the achenes were washed with tap water for $30 \mathrm{~min}$ and then treated with $70 \%(\mathrm{v} / \mathrm{v})$ ethanol for $30 \mathrm{~s}$. After removal of the ethanol, the achenes were disinfected with $3 \%$ sodium hypochlorite $(\mathrm{NaOCl})$ for 10 min. Finally, the disinfected achenes were washed with sterile distilled deionized water three times for $15 \mathrm{~min}$, and then cultured in Murashige and Skoog (MS) (Murashige and Skoog 1962) (Duchefa), and Gamborg's B-5 (B5) (Gamborg et al. 1968) (Duchefa) basal media, each containing $4.7 \mu \mathrm{M}$ kinetin (KIN) (Sigma). At the end of the $30^{\text {th }}$ day, the plantlets were evaluated for germination percentage to determine which of these two main basal media was better suited to $T$. insularum.

\section{Shoot proliferation}

In the shoot multiplication studies, nodal segments obtained from seedling shoots after the third subculture were used as an explant. MS basal medium including vitamins and containing $2 \%(\mathrm{w} / \mathrm{v}$ ) sucrose (Duchefa) and $0.8 \%(\mathrm{w} / \mathrm{v})$ phyto agar (Duchefa) was selected as the most suitable medium for shoot proliferation studies. 6-benzylaminopurine (6-BA, $4.4 \mu \mathrm{M}), \mathrm{KIN}(4.7 \mu \mathrm{M}), 6-(\mathrm{y}, \mathrm{y}-$

dimethylallylamino)-purine (2iP, $4.9 \mu \mathrm{M})$, thidiazuron (TDZ, 4.5 $\mu \mathrm{M})$ and zeatin (ZEA, 4.6 $\mu \mathrm{M})$ in combination with indole-3-butyric acid (IBA), indole-3-acetic acid (IAA) or a-naphthalene acetic acid (NAA) $(0.5 \mu \mathrm{M})$ were added to the medium to support the basic basal medium and increase the shoot multiplication rate. All plant growth regulators (PGRs) used in this study and supplied by Sigma were filter-sterilized with $0.22-\mu \mathrm{m}$ filters, except for 6-BA and NAA, and were added to the cooled media after autoclaving. The $\mathrm{pH}$ of the media was adjusted to 5.8 with $1 \mathrm{M} \mathrm{HCl}$ or $1 \mathrm{M} \mathrm{NaOH}$ before autoclaving. All cultures were maintained at $24 \pm 2^{\circ} \mathrm{C}$ under a $16 / 8 \mathrm{~h}$ photoperiod at a photosynthetic flux of $50 \mu \mathrm{mol} \mathrm{m}^{-2} \mathrm{~s}^{-1}$, provided by cool daylight fluorescent lamps. The subculturing protocol was performed every four weeks. Multiplication rates were calculated by assessing the number of shoots per explant, length of shoots, the number of leaves on each shoot, callus formation, and plant quality (internode length and shoot thickness).

\section{Nuclear DNA content}

Flow cytometry was used to check for the stability of nuclear DNA content as well as ploidy level in in vitro derived shoots of $T$. insularum. The leaves of 30-day-old seedlings and of shoots multiplied on MS media supplemented with cytokinins (KIN, 2iP, TDZ, 6BA and ZEA) and auxins (IBA, IAA, and NAA) were used for flow cytometric analysis. Leaf fragments of the sample plant and the standard plant (Zea mays L.) were chopped up using a razor blade in $1 \mathrm{~mL}$ of woody plant buffer (Loureiro et al. 2007, 0.2 M Tris HCl, $4 \mathrm{mM} \mathrm{MgCl}_{2} \cdot 6 \mathrm{H}_{2} \mathrm{O}, 2 \mathrm{mM}$ EDTA, $\mathrm{Na}_{2} \cdot 2 \mathrm{H}_{2} \mathrm{O}, 86 \mathrm{mM} \mathrm{NaCl}, 10 \mathrm{mM} \mathrm{K}_{2} \mathrm{~S}_{2} \mathrm{O}_{5}, 1 \%$ PVP-10, $1 \%$ (v/v) Triton X-100, pH 7.5), supplemented with $50 \mu \mathrm{g} \mathrm{mL}^{-1}$ propidium iodide and $50 \mathrm{\mu g} \mathrm{mL}^{-1}$ DNase-free RNase, filtered through a 30- $\mu \mathrm{m}$ mesh and stored on ice, in the dark, until measurement. Three independent samples were extracted, filtered and then measured using a BD Accuri ${ }^{\text {TM }} \mathrm{C} 6$ instrument. Usually 10.000 nuclei per sample were analysed for nuclear DNA content and absolute values (Inceer et al. 2016). DNA content was then calculated from mean values of $\mathrm{G} 1$ peaks according to the following formula:

Sample 2C DNA content $=\frac{(\text { sample G1 peak mean }) x(\text { standard } 2 C \text { DNA content })}{\text { standard } G 1 \text { peak mean }}$

\section{Root induction}

MS media, each individually supplemented with $2.5 \mu \mathrm{M}$ IBA, $2.9 \mu \mathrm{M}$, IAA and $2.7 \mu \mathrm{M}$ NAA and without growth regulators, were again selected for rooting the well-proliferated and sufficiently elongated shoots $(\geq 20 \mathrm{~mm})$. Four weeks after the transfer of shoots to the root media, the rooting percentage, number of roots per shoot, root length and secondary root number (lateral roots on the longest root) were calculated to evaluate the rooting success. Each experiment was carried out in triplicate.

\section{Acclimatization}

After rooting studies, rooted and well-developed plants were selected to determine their survival rates under greenhouse conditions as well as in the botanical garden. The greenhouse humidity and temperature were adjusted to $80-85 \%$ and $26 \pm 2{ }^{\circ} \mathrm{C}$, respectively. After 
30 days, the plants were moved to a field in the botanical garden. While 100\% peat was employed in the greenhouse, 1:1 (v/v) peat and forest soil was used for transferring the plantlets to the botanical garden.

\section{Statistical analysis}

For all germination experiments, five achenes were placed into each Magenta vessel, and four vessels were prepared per treatment. Each treatment was performed in triplicate. Statistical differences between obtained from shoot proliferation, root induction and flow cytometric studies were calculated on Statistical Package for the Social Sciences software (SPSS version 21). Duncan's multiple range test (DMRT, 95\% confidence level) from one-way analysis of variance (ANOVA) was used to detect the statistical significance of differences among the mean values in shoot multiplication and root induction. Nuclear DNA data were evaluated using ANOVA and Dunnett's test at $P=0.05$.

\section{Results}

\section{In vitro germination}

The first germination data were obtained at the end of days 8 and 10 after inoculation of the achenes in MS and B5 media, respectively. The MS medium had a greater effect than B5 medium, and yielded $8 \%$ more achene germination. Fifty-eight percent germination success was obtained in MS medium, compared to 50\% in B5 medium. These two culture media exhibited significant differences in terms of numbers of germination achenes, $(P<0.05)$. MS medium was therefore employed in subsequent shoot multiplication studies of $T$. insularum.

\section{Shoot proliferation}

In micropropagation studies, the addition of PGRs to the basal media makes a significant contribution to growth development factors such as length of shoots, lateral shoot formation, and shoot thickness. Furthermore, these PGRs added as cytokinin and auxin combinations differ depending on the plant species and basal medium components. In vitro shoot proliferation from nodal explants was successfully achieved after 4 weeks. MS media supplemented with ZEA and IAA, ZEA and IBA or cytokinin and auxin-free media were found to be more effective in terms of all the tested parameters in shoot proliferation studies for $T$. insularum.

The maximum shoot number per explant $(3.33 \pm 0.48)$ for this species was recorded with MS medium supplemented with $4.6 \mu \mathrm{M} Z \mathrm{EA}$ and $0.5 \mu \mathrm{M}$ IAA (Fig. 1a). Besides, TDZ applications gave lower values in terms of shoot numbers, and there were significant differences between these and other applications. MS medium with the same added cytokinin and auxin combination again reached the highest shoot elongation values with $39.68 \pm 3.33 \mathrm{~mm}$. Surprisingly, the cytokinin and auxin-free MS medium yielded the same shoot length value as MS medium with added $4.6 \mu \mathrm{M}$ ZEA and $0.5 \mu \mathrm{M}$ IAA (Table 1; Fig. 1a). On the other hand, MS medium containing 6-BA combined with any auxin was found to be unsuitable in terms of shoot length among all the applied cytokinin and auxin combinations. The lowest shoot length $(13.48 \pm 1.32)$ for this species was obtained from MS media containing 4.4 $\mu \mathrm{M} 6$-BA and 0.5 IAA $\mu \mathrm{M}$ (Table 1). Significant differences were also observed between ZEA as well as control application and other applied cytokinins in terms of shoot length $(P<0.05)$.

In contrast to the mean values for shoot number and shoot length, MS medium supplemented with $4.6 \mu \mathrm{M}$ ZEA and $0.5 \mu \mathrm{M}$ IBA yielded the highest node number value with $10.67 \pm 0.76$ nodes per explant. An interesting result for this parameter was also obtained from control with $10.46 \pm 1.06$ nodes per explant (Table 1). On the other hand, there were significant differences between these two applications and the others $(P<0.05)$.

In the present study, evaluation of callus formation has revealed a significant response in all applications except for control and KIN plus IAA applications. Among all the treatments, TDZ in combination with IBA or IAA were more effective than other treatments in callus formation. TDZ in combination with IBA or IAA alone resulted in $100 \%$ callus formation. Although ZEA and NAA (54.17\%) and 2iP and IAA (50\%) combinations also caused significant callus formation, statistically significant differences were observed between TDZ and these two applications (Table 1).

\section{Root induction}


The healthy shoots above $20 \mathrm{~mm}$ elongation were cultured in MS medium containing individually $2.5 \mu \mathrm{M}$ IBA, $2.9 \mu \mathrm{M}$ IAA, and $2.7 \mu \mathrm{M}$ NAA, or auxin-free for root induction. The culture conditions during root initiation and root growth were the same as the shoot formation conditions. The obtained rooting successes differed according to the tested auxin type at the end of the $4^{\text {th }}$ week. Only IAA application yielded $100 \%$ rooting success for all tested plantlets. In contrast, the highest values in terms of the evaluated rooting parameters were obtained from auxin-free and NAA supported MS media.

Although there was little difference between the four tested different media in terms of root formation times, the first root was seen on day 19 in MS medium supplemented with $2.7 \mu \mathrm{M}$ NAA. Approximately $20 \mathrm{~mm}$ of root formation in culture conditions may be sufficient for acclimatization studies (Fig. 1b). However, the seedlings were kept in culture medium for four weeks due to the delayed initial root induction and in order to keep culture times equal to shoot formation times. Depending on the first root formation, the highest root numbers, as well as secondary root numbers, were obtained from this medium with $2.46 \pm 0.48$ and $17.63 \pm 0.91$, respectively (Table 2). The differences between the highest and the lowest root number were shown in Table $2(P<0.05)$. An efficient root length was observed in auxin-free medium with $59.1 \pm 3.91 \mathrm{~mm}$, compared with other auxin-treated media (Fig. 2). The lowest mean root length with $46.33 \pm 3.41 \mathrm{~mm}$ among the groups was observed in MS medium supplemented with $2.5 \mu \mathrm{M}$ IBA. Significant differences were determined in terms of root length values between all the tested media for root induction $(P<0.05)$.

\section{Genetic stability}

The results obtained from flow cytometry analysis of propidium iodide-stained nuclei are summarized in Table 1. As shown in Table 1 , nuclear DNA content (2C-values) ranges from $5.85 \mathrm{pg}$ in $4.7 \mu \mathrm{M} \mathrm{KIN} \mathrm{combined} \mathrm{with} 0.5 \mu \mathrm{M}$ IAA to $7.05 \mathrm{pg}$ in $4.7 \mu \mathrm{M}$ KIN combined with $0.5 \mu \mathrm{M}$ NAA. There are no significant differences in $2 \mathrm{C}$-values between regenerated plantlets and plants from natural population, except for the regenerated plantlets in MS media supplemented with $4.7 \mu \mathrm{M} \mathrm{KIN}$ and $0.5 \mu \mathrm{M}$ IBA, $4.6 \mu \mathrm{M}$ ZEA and 0.5 $\mu \mathrm{M}$ IBA, $4.7 \mu \mathrm{M}$ $\mathrm{KIN}$ and $0.5 \mu \mathrm{M}$ NAA, $4.4 \mu \mathrm{M}$ 6-BA and $0.5 \mu \mathrm{M}$ NAA and $4.9 \mu \mathrm{M} 2 \mathrm{iP}$ and $0.5 \mu \mathrm{M}$ NAA. On the other hand, all regenerated plantlets have the same ploidy level $(2 x)$ as plants from natural population.

\section{Ex situ collection}

The rooted and well-developed plantlets were initially acclimatized under greenhouse conditions. The plants were healthy, green and grew rapidly as well as some of them also formed buds and then bloomed under greenhouse conditions (Fig. 1c and 1d). The survival frequency was approximately $76 \%$ for $T$. insularum under greenhouse conditions (Fig. 3). After 30 days, the plants were moved to a field in the botanical garden. After a month, they developed new leaves, and some also formed buds and then bloomed (Fig. 1e and 1f). The survival frequency was approximately $74 \%$ for $T$. insularum under botanical garden conditions. The micropropagated plants were phenotypically indistinguishable from their seed-derived counterparts.

\section{Discussion}

In vitro culture of plant tissues has been used in conservation programs for many threatened species and is especially important in small populations (Gonçalves et al. 2010; Mallón et al. 2011). At the same time, during in vitro culture of the plant tissues, the explant type, its orientation in the culture medium, and the types and concentrations of plant growth regulators in the medium can play a significant role in controlling the differentiation processes, while the choice of explant varies by species (Coste et al. 2012). In Turkey, T. insularum, a critically endangered endemic species, is face the risk of extinction because of several anthropogenic pressures in its habitat and thus, the species is in urgent need of conservation. The present study is the first report of a successfully developed micropropagation protocol for the in vitro culture of T. insularum using nodal segments in MS media supplemented with cytokinin (6BA, KIN, 2iP, TDZ and ZEA) and auxin (IAA, IBA and NAA). Additionally, it is noteworthy to study ex situ conservation of this species as well as the genus Tripleurospermum.

The present results indicate that the rate of in vitro achene germination in T. insularum were relatively low because of recalcitrant, which is in line with our previous ex vitro germination test for chromosome counting (Inceer and Hayırlıoglu-Ayaz 2014, data not shown). Leyva-Peralta et al. (2019) noted that the low seed germination yields have attributed to the heterogeneous maturation of the seeds in the Asteraceae, resulting in a high proportion of empty seeds. According to Benson (2000b) and Leyva-Peralta et al. (2019), recalcitrance is the inability of plant cells, tissues, and organs to respond to tissue culture. However, the obtained seedlings of $T$. insularum were vigorous and suitable for use as a source of explants. 
Different in vitro culture media supplemented with PGRs have been used for in vitro culture of other members of Asteraceae (Evenor and Reuveni 2004; Mallón et al. 2011; Shinde et al. 2017) with the MS basal medium being the most applied one. Similarly, shoot production of T. insularum was enhanced when shoot nodal explants were cultured in MS medium, which proved to be the most adequate medium tested.

The combinations of cytokinins and auxins have been used to induce shoots from different types of explants in many members of the family Asteraceae (Nikam and Shitole 1998; Sivaram and Mukundan 2003; Radhika et al. 2006; Enyew and Feyissa 2019). On the other hand, MS medium with 6-BA and IAA combination was found to yield a better response for shoot production in some members of the tribe Anthemideae of Asteraceae (Echeverrigaray et al. 2000; Evanor and Rauveni 2004). However, in this study, the use of 4.5 $\mu \mathrm{M}$ TDZ plus $0.5 \mu \mathrm{M}$ IBA as well as $4.4 \mu \mathrm{M}$ 6-BA plus $0.5 \mu \mathrm{M}$ IAA resulted in the lower shoot number and length respectively, indicative that they are not as effective in shoot regeneration for T. insularum (Table 1). Among the various growth regulators tested, the best proliferation of shoots was obtained on the MS medium with 4.6 $\mu \mathrm{M}$ ZEA and $0.5 \mu \mathrm{M}$ IAA combination (Table 1). Besides, depending on the using $4.6 \mu \mathrm{M}$ ZEA plus $0.5 \mu \mathrm{M} \mathrm{IAA}$, there is no statistically difference in nuclear DNA content and ploidy level between in vitro and in vivo plants, indicative that they maintain their genetic stability during in vitro culture. These findings show that MS medium containing $4.6 \mu \mathrm{M}$ ZEA plus $0.5 \mu \mathrm{M}$ IAA are the most favorable for shoot proliferation of $T$. insularum. The present results are in agreement with the previous report in Helichrysum italicum (Roth) G.Don (Asteraceae) (Giovannini et al. 2003)

The present results show that the percentage of the callus formation is very high in MS medium supplemented with $4.5 \mu \mathrm{M}$ TDZ and $0.5 \mu \mathrm{M}$ IBA as well as $4.5 \mu \mathrm{M}$ TDZ and $0.5 \mu \mathrm{M}$ IAA (Table 1). Additionally, the use of $4.5 \mu \mathrm{M}$ TDZ in combination with $0.5 \mu \mathrm{M}$ IBA resulted in the lower shoot number and length, indicative that they are not as effective in shoot regeneration for this species Similar results are reported from other species of Asteraceae such as Gerbera jamesonii H. Bolus ex Hook (Chakrabarty and Datta 2008), and Stevia rebaudiana Bertoni (Zayova et al. 2013).

The auxins such as IAA, IBA and NAA in MS media have been used in different concentrations for rooting in the members of the Asteraceae family (Cardoso and Silva 2013; Shinde et al. 2017). Some members of Asteraceae developed in vitro roots on medium free of PGRs, while others required the presence of PGRs in medium to form roots (Trejgell et al. 2010, 2018; Opadobe et al. 2017). According to Opadobe et al. (2017), the incidence of root formation on auxin-free medium may be due to the presence of endogenous auxin in regenerated shoots. In Saussurea obvallata (DC.) Edgew, the presence of auxin increased numbers of rooted shoots and numbers of roots per shoot (Joshi and Dhar 2003). Perica et al. (2008) reported that the highest rooting percentage (100\%) from shoot explants of Inula verbascifolia (Willd.) Hausskn was observed on MS medium supplemented with $2.9 \mu \mathrm{M}$ IAA. Owies et al. (2004) also noted that MS medium supplemented with $2.7 \mu \mathrm{M}$ NAA yielded a better response for root number in another species Gundelia tournefortii L. of Asteraceae. In the present study, the rooting has occurred both with and without auxin in all tested media, but the presence of auxin greatly increased the rooting rate compared to auxin-free medium at the end of the $4^{\text {th }}$ week (Table 2$)$. Using $2.9 \mu \mathrm{M}$ IAA resulted in the maximum rooting frequency (100\%). On the other hand, the maximum root number $(2.46 \pm 0.48)$ as well as secondary root number $(17.63 \pm 0.91)$ per explant were obtained from MS medium supplemented with $2.9 \mu M$ NAA (Table 2). On the contrary, auxin free MS medium yielded a better response for root length. The present results revealed that IAA and NAA were more effective than IBA in the induction of roots in regenerated shoots of $T$. insularum. Additionally, the incidence of root formation on auxin-free medium may be due to the presence of endogenous auxin in regenerated shoots.

According to (Dolezel et al. 2007), mixoploidy, polyploidy and aneuploidy can occur in in vitro plant cultures and are particularly undesireable in regenerants. Compared with the natural environment, in vitro culture is more complicated and stressful, which is more likely to cause genetic variation (Bauri et al. 2011; Cui et al. 2019). Therefore, it is necessary to assess the genetic uniformity of the regenerated plants before confirming the success of a micropropagation protocol as well as reintroduction to natural sites or planting in botanic gardens (Slazak et al. 2015). For the last several years, the flow cytometry technique was extensively used to verify the genetic fidelity of micropropagated plants (Bairu et al. 2011; Ochatt et al. 2011; Slazak et al. 2015; Żabicki et al. 2019). For Asteraceae micropropagation protocols, the genetic uniformity of regenerated plants has been estimated by flow cytometry (Sliwinska and Thiem 2007; Mallón et al. 2010). In our study, all regenerated plantlets of $T$. insularum possessed the same ploidy ( $2 x$, i.e. diploid) as initial plants and plants from natural populations. Besides, most regenerated plantlets had almost similar nuclear DNA content, while previously published data for this species from natural population were slightly lower (Inceer et al. 2018). These findings indicated genetic uniformity of regenerated plantlets obtained via direct shoot formation on MS media supplemented with PGRs. On the other hand, using KIN plus IBA, ZEA plus IBA, KIN plus NAA, 6-BA plus NAA and 2iP plus NAA yielded higher 2C-values in 
regenerated plantlets of $T$. insularum. The significant differences in $2 \mathrm{C}$-values of these regenerated plantlets may represent genetic variations based on mutations in DNA.

\section{Conclusion}

This study is the first report of the efficient in vitro propagation of threatened insular endemic $T$. insularum. Nodal explants were used as excellent starting material for axillary shoot multiplication. Multiple shoots possessed almost the same nuclear DNA content as native plants, except when they were grown on medium supplemented with KIN plus IBA, ZEA plus IBA, KIN plus NAA, 6-BA plus NAA, and $2 \mathrm{iP}$ plus NAA. Additionally, the present results confirm that the proposed protocol guarantees in vitro production of $T$. insularum with genetic stability. The plants obtained in vitro via direct organogenesis exhibited normal development, were fertile, and seemed to adapt well to the botanical garden. Hence, this protocol may be used in future conservation programs such as in situ activities on population restoration and cryopreservation of this species as well as other threatened endemic species of Tripleurospermum.

\section{Abbreviations}

MS Murashige and Skoog medium

6-BA 6-Benzylaminopurine

KIN Kinetin (6-furfurylaminopurine)

ZEA Zeatin

2iP 6-(Y,Y-Dimethylallylamino)purine

IAA Indole-3-acetic acid

IBA Indole-3-butyric acid

TDZ Thidiazuron (N-phenyl-N'- 1,2,3-thiadiazol-5'-ylurea)

NAA a -napthalene acetic acid

PGR Plant growth regulator

CONT Control

\section{Declarations}

Acknowledgements The authors are most grateful to the Karadeniz Technical University, Faculty of Forestry greenhouse personnel for ex vitro studies.

\section{Funding}

This work was supported by the Scientific and Technological Research Council of Turkey [TUBITAK project no (grant numbers) $117 Z 588$ and 106T162].

\section{Compliance with ethical standards}

Conflict of interest The authors declare that they have no confict of interest.

\section{References}

1. Altundag E, Ozturk M (2011) Ethnomedicinal studies on the plant resources of east Anatolia, Turkey. Procedia - Soc Behav Sci 19:756-777. 
2. Assédé ESP, Djagoun CAMS, Azihou FA, Gogan YSC, Kouton MD, Adomou AC, Geldenhuys CJ, Chirwa PW, Sinsin B (2018) Efficiency of conservation areas to protect orchid species in Benin, West Africa. S Afr J Bot 116:230-237.

3. Bairu MW, Aremu AO, Van Staden J (2011) Somaclonal variation in plants: causes and detection methods. Plant Growth Regul 63:147-173.

4. Bellard C, Leclerc C, Courchamp F (2013) Impact of sea level rise on the 10 insular biodiversity hotspots. Glob Ecol Biogeogr 23:203-212.

5. Benson E, Danaher JE, Pimbley IM, Anderson CT, Wake JE, Daley S, Adams LK (2000a) In vitro micropropagation of Primula scotica: A rare Scottish plant. Biodivers Conserv 9:711-726. https://doi.org/10.1023/A:1008941726419

6. Benson EE (2000b) In vitro Plant Recalcitrance: An Introduction. In vitro Cell Dev Biol Plant 36:141-148.

7. Cañadas EM, Fenu G, Peñas J, Lorite J, Mattana E, Bacchetta G (2014) Hotspots within hotspots: Endemic plant richness, environmental drivers, and implications for conservation. Biol Conserv 170:282-291.

8. Cansaran A, Kaya OF, Yıldırım C (2007) Ovabaşı, Akpınar, Güllüce ve Köseler köyleri (Gümüşhane/ Amasya) arasında kalan bölgede etnobotanik bir araştırma. Fırat Üniversitesi Fen Müh Bil Derg 19:243-257.

9. Cardoso J, Teixeira da Silva J (2013) Gerbera Biotechnol Adv 31:1344-1357. https://doi.org/10.1016/j.biotechadv.2013.05.008

10. Caujapé-Castells J, Tye A, Crawford DJ, Santos-Guerra A, Sakai A, Beaver K, Lobin W, Vincent Florens FB, Moura M, Jardim R, Gómes I, Kueffer C (2010) Conservation of oceanic island floras: Present and future global challenges. Perspect Plant Ecol Evol Syst 12:107-129.

11. Chakrabarty D, Datta SK (2008) Micropropagation of Gerbera: lipid peroxidation and antioxidant enzyme activities during acclimatization process. Acta Physiol Plant 30:325-331.

12. Cogoni D, Sulis E, Bacchetta G, Fenu G (2019) The unpredictable fate of the single population of a threatened narrow endemic Mediterranean plant. Biodivers Conserv 28:1799-1813. https://doi.org/10.1007/s10531-019-01757-0

13. Colak N, Inceer H, Gruz J, Strnad M, Hayirlioglu-Ayaz S, Aksu N, Ayaz F (2017) Antioxidant capacity of phenolics in some representatives of the tribe Anthemideae (Asteraceae) from Turkey. Int J Pharm Sci 8: 3265-3277.

14. Corral P, Mallón R, Rodríguez-Oubiña J, González ML (2011) Multiple shoot induction and plant regeneration of the endangered species Crepis novoana. Plant Cell Tissue Organ Cult 105:211-217. https://doi.org/10.1007/s11240-010-9854-x

15. Coste A, Halmagyi A, Butiuc-Keul AL, Deliu C, Coldea G, Hurdu (2012) In vitro propagation and cryopreservation of Romanian endemic and rare Hypericum Plant Cell Tissue Organ Cult 110:213-226.

16. Cui Y, Deng Y, Zheng K, Hu X, Zhu M, Deng X, Xi R (2019) An efficient micropropagation protocol for an endangered ornamental tree species (Magnolia sirindhorniae \& Chalermglin) and assessment of genetic uniformity through DNA markers. Sci Rep 9:9634.

17. Deplazes-Zemp A (2018) 'Genetic resources', an analysis of a multifaceted concept. Biol Conserv 222:86-94. https://doi.org/10.1016/j.biocon.2018.03.031

18. Doležel J , Greilhuber J, Suda J (2007) Flow Cytometry with Plant Cells: Analysis of Genes, Chromosomes and Genomes. WileyVCH Verlag GmbH \& Co KGaA.

19. Echeverrigaray S, Fracaro F, Andrade LB, Biasio S, Atti-Serafini L (2000) In vitro shoot regeneration from leaf explants of Roman Chamomile. Plant Cell Tissue Organ Cult 60:1-4. https://doi.org/10.1023/A:1006368210670

20. Enyew M, Feyissa T (2019) In vitro shoot regeneration from leaf explants of Echinops kebericho: an endangered endemic medicinal plant. Plant Biosyst - Int J Deal Asp Plant Biol 153:199-204. https://doi.org/10.1080/11263504.2018.1448014

21. Evenor D, Reuveni M (2004) Micropropagation of Achillea filipendulina 'Parker.' Plant Cell Tissue Organ Cult 79:91-93.

22. Gamborg OL, Miller RA, Ojima K (1968) Nutrient requirements of suspension cultures of soybean root cells. Exp Cell Res 50:151158.

23. Giovannini A, Amoretti M, Savona M, Guardo A, Ruffoni B (2003) Tissue culture in Helichrysum Acta Hortic 616:339-342.

24. Gonçalves S, Fernandes L, Romano A (2010) High-frequency In vitro propagation of the endangered species Tuberaria major. Plant Cell Tissue Organ Cult 101:359-363.

25. Gray A (2018) The ecology of plant extinction: rates, traits and island comparisons. Oryx 53:1-5. https://doi.org/10.1017/S0030605318000315

Page 8/14 
26. Grigoriadou K, Krigas N, Maloupa E (2011) GIS-facilitated in vitro propagation and ex situ conservation of Achillea occulta. Plant Cell Tissue Organ Cult 107:531-540.

27. Han MI, Bulut G (2015) The folk-medicinal plants of Kadişehri (Yozgat - Turkey). Acta Soc Bot Pol 84:237-248. https://doi.org/10.5586/asbp.2015.021

28. Harter DEV, Irl SDH, Seo B, Steinbauer MJ, Gillespie R, Triantis KA, Fernández-Palacios J-M, Beierkuhnlein C (2015) Impacts of global climate change on the floras of oceanic islands - Projections, implications and current knowledge. Perspect Plant Ecol Evol Syst 17:160-183.

29. Inceer H, Aksu N, Imamoğlu K, Duman O, Hayirlioglu-Ayaz S, Arslan G (2016) Micromorphological, anatomical and cytogenetical studies in endemic Crepis macropus \& Heldr. (Asteraceae) from Turkey. Acta Bot Croat 75:173-178.

30. Inceer H, Garnatje T, Hayırlıoğlu-Ayaz S, Pascual-Díaz JP, Vallès J, Garcia S (2018) A genome size and phylogenetic survey of Mediterranean Tripleurospermum and Matricaria (Anthemideae, Asteraceae). Plos One 13:10.

31. Inceer H, Hayırlığlu-Ayaz S (2014) Tripleurospermum insularum (Asteraceae, Anthemideae), a new species from Turkey. Ann Bot Fenn 51:49-53.

32. Inceer H, Kalmuk N (2019) Conservation assessment of some rare and endemic Crepis (Asteraceae) taxa in Turkey. https://doi.org/10.24189/ncr.2019.056

33. Joshi M, Dhar U (2003) In vitro propagation of Saussurea obvallata (DC.) Edgew. -an endangered ethnoreligious medicinal herb of Himalaya. Plant Cell Rep 21:933-939.

34. Kueffer C, Daehler CC, Torres-Santana CW, Lavergne C, Meyer J-Y, Otto R, Silva L (2010) A global comparison of plant invasions on oceanic islands. Perspect Plant Ecol Evol Syst 12:145-161. https://doi.org/10.1016/j.ppees.2009.06.002

35. Leyva-Peralta AL, Salcedo-Morales G, Medina-Pérez V, López-Laredo AR, Trejo-Espino JL, Trejo-Tapia G (2019) Morphogenesis and in vitro production of caffeoylquinic and caffeic acids in Baccharis conferta In Vitro Cell Dev Biol - Plant 55:581-589.

36. Loureiro J, Rodriguez E, Doležel J, Santos C (2007) Two new nuclear isolation buffers for plant DNA flow cytometry: A test with 37 species. Ann Bot 100:875-888.

37. Mallón R, Rodríguez-Oubiña J, González M (2010) In vitro propagation of the endangered plant Centaurea ultreiae: assessment of genetic stability by cytological studies, flow cytometry and RAPD analysis. Plant Cell Tissue Organ Cult 101:31-39. https://doi.org/10.1007/s11240-009-9659-y

38. Mallón R, Rodríguez-Oubiña J, González M (2011) Shoot regeneration from in vitro-derived leaf and root explants of Centaurea ultreiae. Plant Cell Tissue Organ Cult 106:523-530. https://doi.org/10.1007/s11240-011-9934-6

39. Médail F (2017) The specific vulnerability of plant biodiversity and vegetation on Mediterranean islands in the face of global change. Reg Environ Change 17:1775-1790. https://doi.org/10.1007/s10113-017-1123-7

40. Perica MC, Vršek I, Mitić B (2008) In vitro propagation of Inula verbascifolia (Willd.) Hausskn. subsp. verbascifolia. 142:11263504.

41. Mohammadi H, Sajjadi S-E, Noroozi M, Mirhosseini M (2016) Collection and assessment of traditional medicinal plants used by the indigenous people of Dastena in Iran. J HerbMed Pharmacol 5:54-60.

42. Murashige T, Skoog F (1962) A revised medium for rapid growth and bioassays with Tobacco tissue cultures. Physiol Plant 15:473-497.

43. Nikam TD, Shitole MG (1998) In vitro culture of Safflower L. cv. Bhima: initiation, growth optimization and organogenesis. Plant Cell Tissue Organ Cult 55:15-22.

44. Oberprieler C, Vogt R, Watson LE, (2007) XVI. Tribe Anthemideae Cass. (1819). In: Kadereit, JW, Jeffrey C (Eds) Flowering plants, eudicots. In: Kubitzki, K. (Ed.), The Families and Genera of Vascular Plants, 8th edn. Springer-Verlag, Berlin Heidelberg, pp 342374.

45. Ochatt SJ, Patat-Ochatt EM, Moessner A (2011) Ploidy level determination within the context of in vitro Plant Cell Tissue Organ Cult 104:329-341.

46. Opabode JT, Ajibola OV, Lamidi T (2017) In vitro propagation of Crassocephalum crepidioides - An endangered African traditional leaf vegetable and molecular analysis of micropropagated plants. Int J Veg Sci 23:18-30.

47. Owies DS, Shibli RA, Ereifej KI (2004) In vitro propagation of Gundelia tournefortii Adv Hortic Sci 18:127-131. 
48. Perica MĆ, Vršek I, Mitić B (2008) In vitro propagation of Inula verbascifolia (Willd.) Hausskn. subsp. verbascifolia. Plant Biosyst Int J Deal Asp Plant Biol 142:1-4.

49. Piovan A, Rosy C, Cappelletti E, Filippini R (2010) Organogenesis from shoot segments and via callus of endangered Kosteletzkya pentacarpos (L.) Ledeb. Plant Cell Tissue Organ Cult 100:309-315. https://doi.org/10.1007/s11240-009-9652-5

50. Radhika K, Sujatha M, Rao T (2006) Thidiazuron stimulates adventitious shoot regeneration in different safflower explants. Biol Plant 50:174-179.

51. Ramírez-Mosqueda MA, Cruz-Cruz CA, Atlahua-Temoxtle J, Bello-Bello JJ (2019) In vitro conservation and regeneration of Laelia anceps South Afr J Bot 121:219-223.

52. Shinde S, Katewal PR, Shanbhag DD, Joseph KS, Murthy HN (2017) In vitro propagation of Artemisia japonica. J Herbs Spices Med Plants 23:36-43.

53. Sivaram L, Mukundan U (2003) In vitro culture studies on Stevia rebaudiana. In Vitro Cell Dev Biol - Plant 39:520-523. https://doi.org/10.1079/IVP2003438

54. Slazak B, Sliwinska E, Saługa M, Ronikier M, Bujak J, Słomka A, Göransson U, Kuta E (2015) Micropropagation of Viola uliginosa (Violaceae) for endangered species conservation and for somaclonal variation-enhanced cyclotide biosynthesis. Plant Cell Tissue Organ Cult 120:179-190. https://doi.org/10.1007/s11240-014-0592-3

55. Sliwinska E, Thiem B (2007) Genome size stability in six medicinal plant species propagated in vitro. Biol Plant 51:556-558.

56. Trejgell A, Kamińska M, Lisowska K, Tretyn A (2018) Micropropagation of Inula germanica from the Seedlings Explants. Not Bot Horti Agrobot Cluj-Napoca 46:52-57.

57. Trejgell A, Michalska M, Tretyn A (2010) Micropropagation of Senecio macrophyllus Bieb. Acta Biol Cracoviensia Ser Bot 52:6772.

58. Valletta A, Santamaria AR, Fabrini G, Tocci N, Filho VC, Wagner T, Brasili E, Pasqua G (2015) Strategies for ex situ conservation of Centaurea cineraria circae (Asteraceae), an endemic plant from Lazio (Italy). Plant Biosyst - Int J Deal Asp Plant Biol 150:323332. https://doi.org/10.1080/11263504.2014.1001464

59. Wadl PA, Dattilo AJ, Vito LM, Trigiano RN (2011) Shoot organogenesis and plant regeneration in Pityopsis ruthii. Plant Cell Tissue Organ Cult 106:513-516.

60. Żabicki P, Sliwinska E, Mitka J, Sutkowska A, Tuleja M, Migdałek G, Żabicka J, Słomka A, Kwiatkowska M, Kuta E (2019) Does somaclonal variation play advantageous role in conservation practice of endangered species?: comprehensive genetic studies of in vitro propagated plantlets of Viola stagnina (Violaceae). Plant Cell Tissue Organ Cult 136:339-352.

61. Zayova E, Stancheva I, Geneva M, Petrova M, Dimitrova L (2013) Antioxidant activity of in vitro propagated Stevia rebaudiana Bertoni plants of different origins. Turk J Biol 37:106-113.

62. Zeljković SĆ, Ayaz FA, Inceer H, Hayirlioglu-Ayaz S, Colak N (2015) Evaluation of chemical profile and antioxidant activity of Tripleurospermum insularum, a new species from Turkey. Nat Prod Res 29:293-296.

\section{Tables}

Table 1 Effects of different cytokinin in the presence of IBA, IAA and NAA $(0.5 \mu \mathrm{M})$ combination and control group on the shoot proliferation of $T$. insularum as well as nuclear DNA content $(\mathrm{pg} / 2 \mathrm{C} \pm \mathrm{SD})$ in the leaves of $T$. insularum from native individuals and in vitro derived shoots 


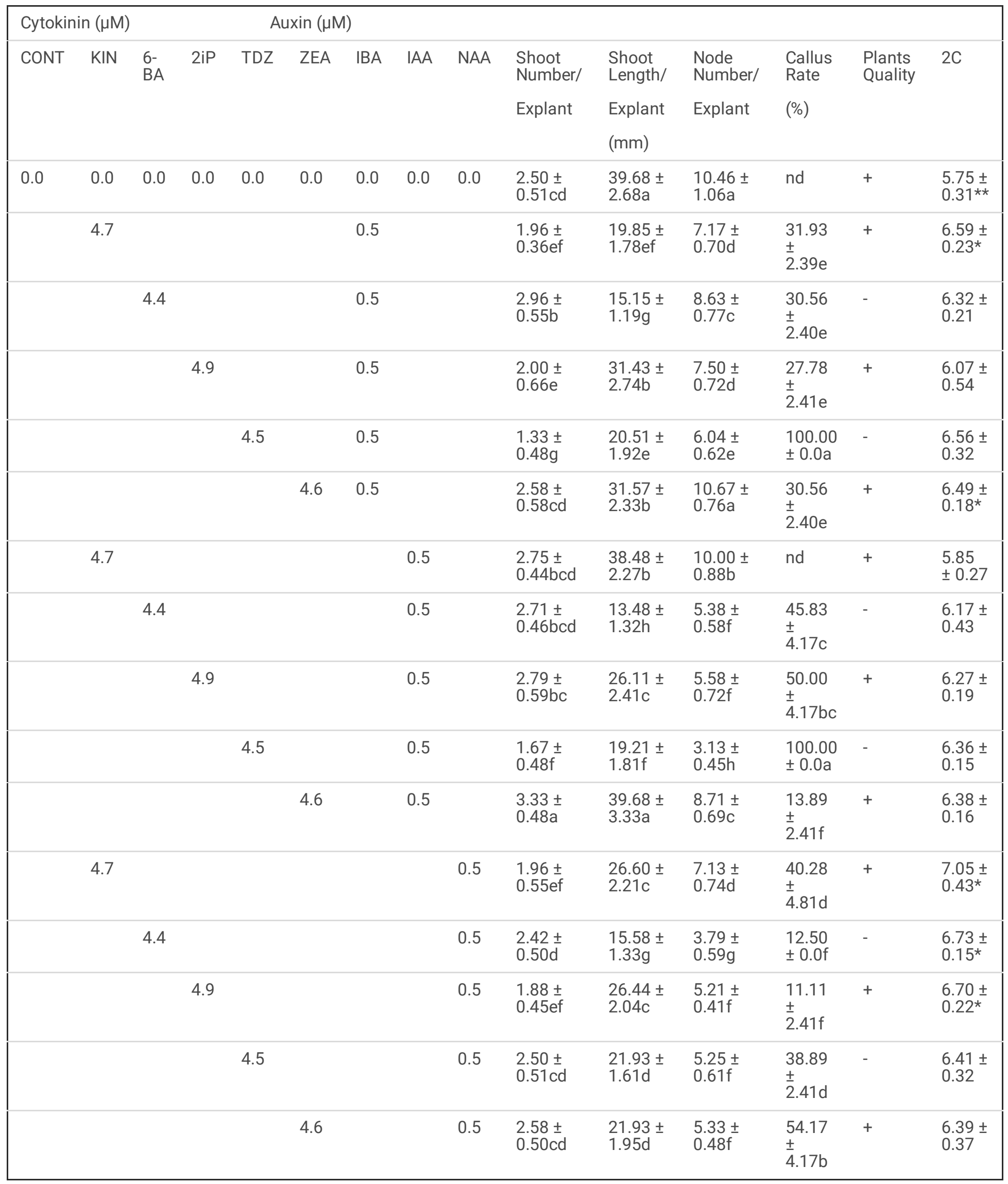

Data were recorded four weeks after the culture and represent a total of three replicates of 24 plants per treatment on MS. Values having the same letter(s) in the same column are not significantly different according to Duncan's multiple range test at $P<0.05$. nd $=$ Not detected 
$* P=0.05, * *$ Native individuals.

Table 2 The effects of different auxin types on in vitro rooting of $T$. insularum shoots

\begin{tabular}{|c|c|c|c|c|}
\hline $\begin{array}{l}\text { PGRs } \\
(\mu \mathrm{M})\end{array}$ & Rooting rate (\%) & $\begin{array}{l}\text { Root Number } \\
\text { (No/Plant) }\end{array}$ & $\begin{array}{l}\text { Root Length } \\
(\mathrm{mm})\end{array}$ & Secondary Root Number (No/Plant) \\
\hline Control & $91.7 \pm 3.6 b$ & $1.65 \pm 0.37 \mathrm{c}$ & $59.1 \pm 3.91 \mathrm{a}$ & $10.8 \pm 0.64 d$ \\
\hline 2.5 IBA & $89.6 \pm 3.6 b$ & $1.82 \pm 0.39 \mathrm{bc}$ & $46.33 \pm 3.41 c$ & $13.8 \pm 1.23 \mathrm{c}$ \\
\hline 2.9 IAA & $100 \pm 0.0 a$ & $2.04 \pm 0.33 b$ & $52.2 \pm 2.91 b$ & $15.08 \pm 0.97 b$ \\
\hline 2.7 NAA & $91.7 \pm 3.6 b$ & $2.46 \pm 0.48 a$ & $52.91 \pm 3.67 b$ & $17.63 \pm 0.91 a$ \\
\hline
\end{tabular}

Data were recorded on the four weeks after the culture and represent a total of three replicates of 16 plants per treatment for root induction.

Values having the same letter(s) in the same column are not significantly different according to Duncan's multiple range test at $P<$ 0.05 .

\section{Figures}



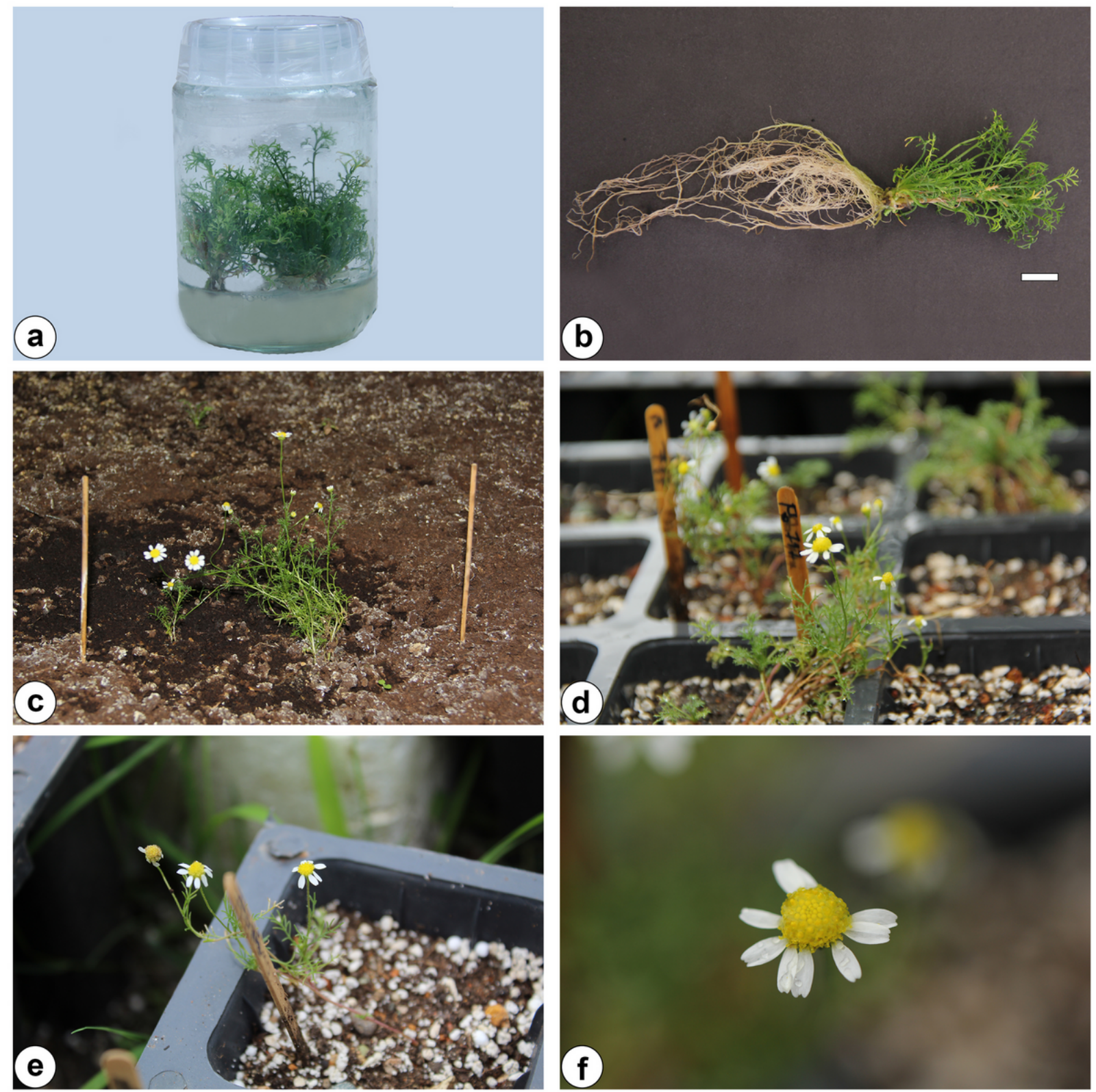

\section{Figure 1}

Micropropagation and ex vitro collections of T. insularum. a 4.6/0.5 $\mu \mathrm{M}$ ZEA/IAA, b 2.7 $\mu \mathrm{M}$ NAA on in vitro rooting of T. insularum from shoot-bud culture-derived seedlings, c, d Greenhouse conditions, e, f Botanical garden conditions, Scale bar: $5 \mathrm{~cm}$ 


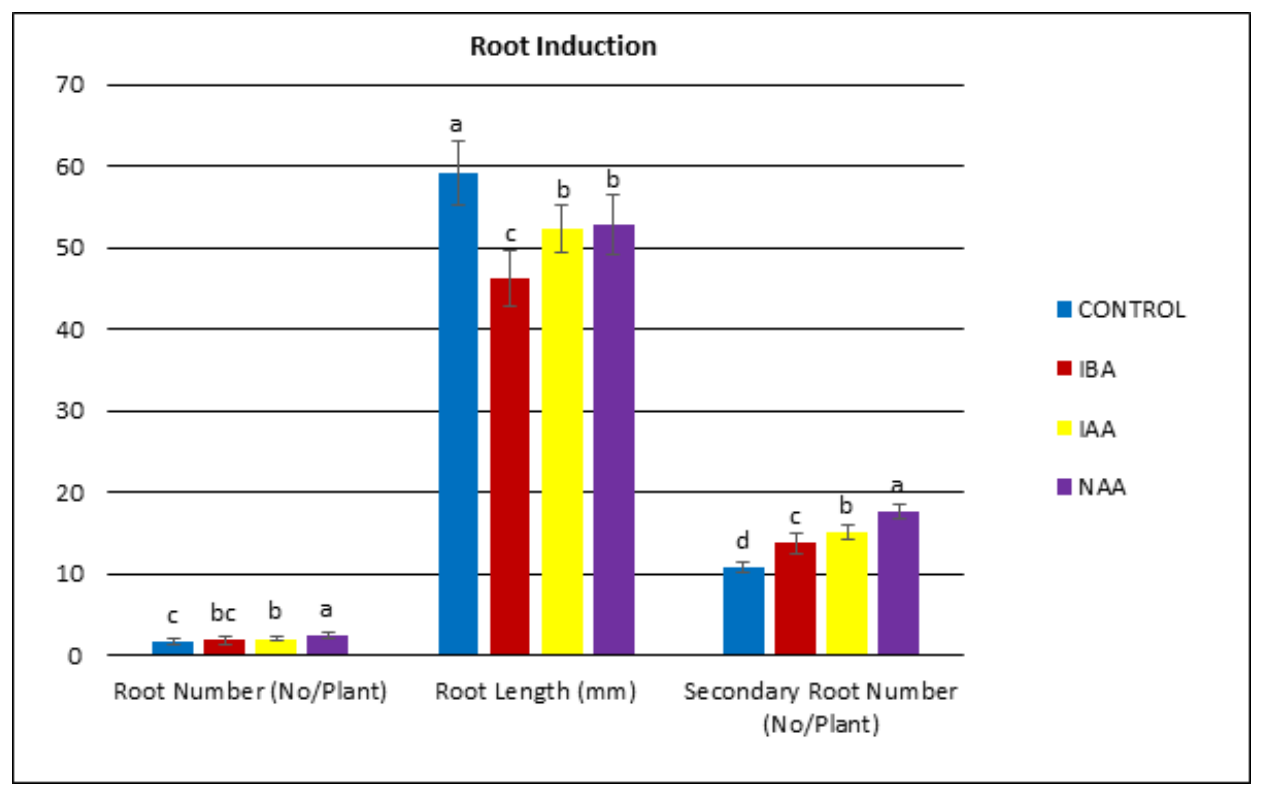

Figure 2

The effects of different auxin types on in vitro rooting of T. insularum shoots

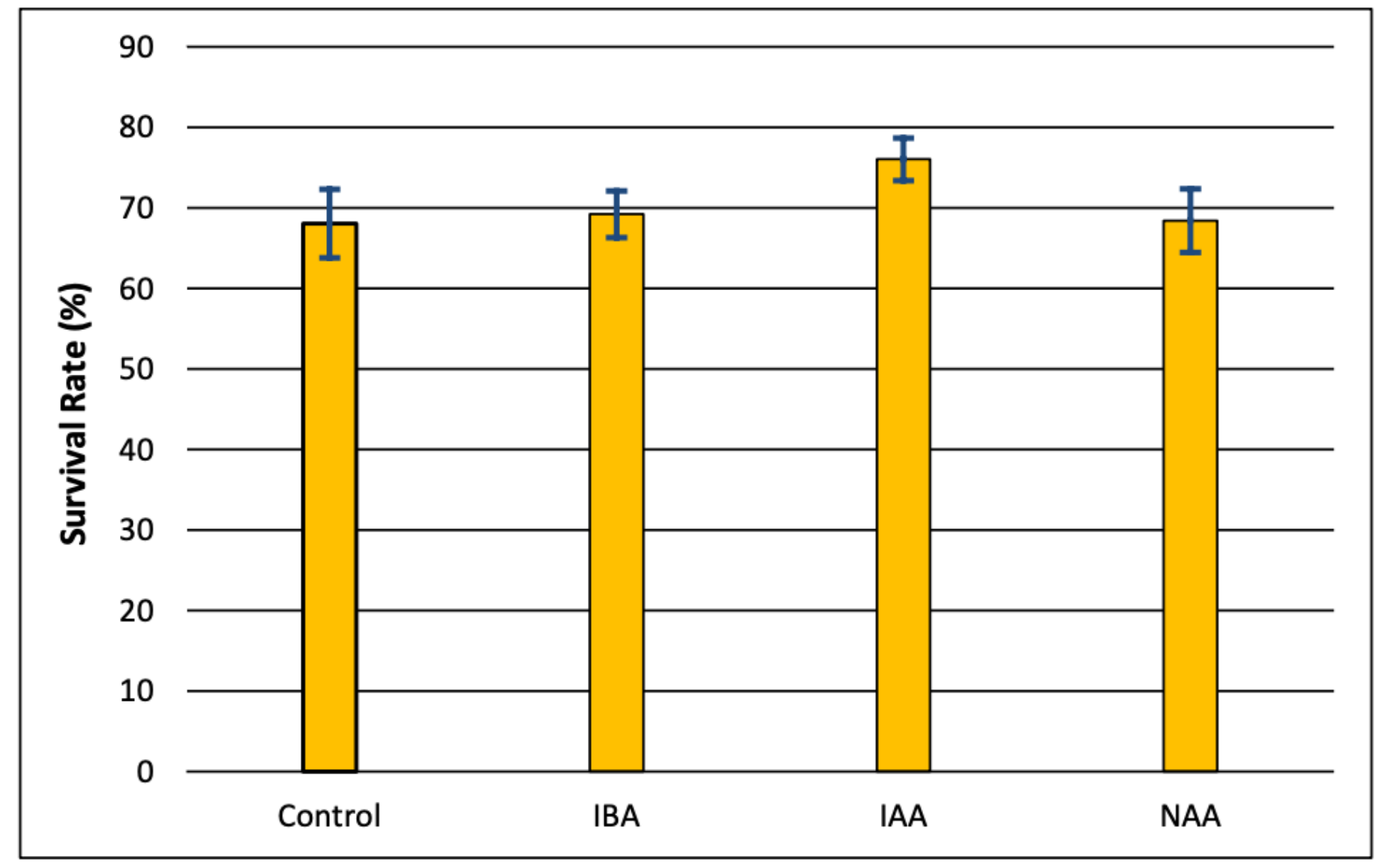

Figure 3

Survival rates of plantlets transferred from different rooting media to the greenhouse conditions 